\title{
IT'S WRONG, BUT THAT'S THE WAY IT IS. YOUTH, VIOLENCE AND JUSTICE IN NORTH-EASTERN BRAZIL
}

This article discusses the vertiginous proliferation of violence suffered and perpetrated by juveniles in the state of Bahia, north-eastern Brazil. Based on documentary and ethnographic evidence, it anatomizes the workings of law enforcement, juvenile justice and juvenile custody. It argues that the strategies of the police, the criminologies put into practice by the judiciary and the functioning of Youth Detention Centres collaborate to foster, rather than curb, youth offending and the violence committed by and against young citizens. Whereas prosecution and the dispensation of justice emphasize juvenile offenders' responsibility for their "decision" to become a "bandit", juvenile custody, as a result of deep-rooted clientelist practices, is dominated by precarious conditions of incarceration which promote internal violence and the (self-)ascription of a deviant juvenile identity. At the same time, the Othering of large sections of youth from the urban periphery has fuelled a vicious cycle of violence and counter-violence between members of drug factions and police forces, resulting in an increasing illegibility of the state at its margins.

Keywords: Bahia, Brazil, gangs, police, trafficking, violence, youth, youth custody, youth justice

The hearings of the juvenile offenders, detained by the police the day before in the city of Salvador, had already terminated when a woman entered the building of the Youth Prosecution Service and asked for permission to talk to the prosecutor on duty. Because of her evident distress, she was shown through at once. As soon as the door of the prosecutor's office was closed behind her, the woman unceremoniously presented herself as the mother of the 13-year-old Jonathan who, a couple of days before, had shot dead a plain-clothes police

\footnotetext{
${ }^{1}$ Centre for Research in Anthropology, University of Minho, Portugal. The research for this article was funded by a postdoctoral scholarship (SFRH/BPD/99782/2014) from the Portuguese Foundation for Science and Technology (FCT).
} 
officer during an assault of a city bus which went awry - an incident well known to all the persons present, as the case had attracted considerable attention in the local media. ${ }^{2}$

During the assault, the officer, who was commuting to work (he didn't own a car, as his family later reported to the press), had managed to shoot and subdue Jonathan's adult accomplice in the front of the bus. However, in the course of the struggle, the older assailant's weapon (a .38 revolver of the Brazilian brand Taurus), fell to the floor, towards the other side of the bus's turnstile. Jonathan, who was by this time busy collecting passengers' cell phones and money at the rear of the bus, quickly ran to the front and, despite being hit in the foot and in the arm by two shots from the officer's weapon, succeeded in snatching the .38 Taurus from the floor, firing two deadly shots towards the policeman's head and chest.

Working as a cleaner in the hospital where the officer arrived shortly afterwards, already lifeless, Jonathan's mother had coincidentally witnessed the suffering of the policeman's family at close range. Her compassion for the deceased and his relatives, which she recounted in detail at the Youth Offending Services, however, soon became mingled with fears regarding her own son's destiny. Another youth, initially suspected of being one of the assailants, was killed on the same day of the bus assault, just after leaving the infirmary where he had been treated for a gunshot wound in the foot. As Jonathan's mother was anxious to stress, her son was willing to turn himself in, but remained in hiding as she was fearful of "the eventual reaction of a normal policeman", as she called it.

The prosecutor assured her that Jonathan, once he presented himself, would be accompanied by an official to the nearby station for juvenile offenders. As Jonathan's mother was unable to get hold of her son by phone, it was agreed that she would bring him along the next morning. On the evening of that same day, however, Jonathan was spotted by the military police ${ }^{3}$ in the neighbourhood where he was hiding out, and shot dead as "he preferred trying to resist" detention, as an officer of the homicide department, cited in a note on the Public Security Authorities' website, put it. ${ }^{4}$

The fates of the 43-year-old policeman and 13-year-old Jonathan from Salvador (the capital city of the state of Bahia) are paradigmatic of the issues I will address in this article. In the first place, they point to the mounting dimension of youth violence and youth offending in

\footnotetext{
${ }^{2}$ All names have been changed. All terms and quotes originally in Portuguese have been translated by the author.

${ }^{3}$ Brazilian police forces are composed of the military (polícia militar) and the civil police (polícia civil). The former are mainly responsible for patrolling the streets, the latter for criminal investigations.

${ }^{4}$ See: www.ssp.ba.gov.br/2017/01/1696/Adolescente-envolvido-em-morte-de-PM-reage-a-abordagem.html (accessed 3 May 2017).
} 
north-eastern Brazil, and the tender age of the juveniles involved. Second, they exemplify the failings of public policies regarding marginalized youths, the state's lack of lack of interest in dealing adequately with those who come into contact with the juvenile justice system, and the persistent institutional marginalization of juvenile offenders who, eventually, are sentenced to serve a term in one of the state's juvenile custody institutions. Third, they give an idea of the senseless suffering caused by an endemic illegibility of the state, particularly at its socioeconomic margins, which makes it increasingly difficult for citizens of all ages to tell the difference between "right" and "wrong", perpetrator and victim, or state action and banditry, resulting in a "doubling" of violence between agents of law enforcement and, mostly juvenile, members of the organized drug trade.

The discussion of this article is based on documentary evidence and longitudinal fieldwork at the Youth Prosecution Service of Salvador, the Juvenile Justice Court of Salvador, and two Youth Detention Centres (YDCs) in the same city. At the Youth Prosecution Service, I was authorized to attend the hearings of juvenile offenders conducted, at the time, by two different public prosecutors. The juveniles presented had generally been arrested the day before by the military police, spending the night in a cell of the specialized police unit for juvenile offenders. ${ }^{5}$ In around 30 of the more than 200 cases I attended, the prosecutors pleaded for pre-trial detention, either due to the violent character of the offence or owing to an offender's repeated arrest for non-violent crimes. At the Juvenile Court (housed in the same building), I was allowed to follow juveniles' trials and take notes during a couple of months, in the course of which a number of different judges presided over the proceedings. Finally, over the course of three years, fieldwork was carried out (during a total of six and four months, respectively) in a semi-secure and a secure YDC in Salvador. ${ }^{6}$ There, I was authorized to spent the day at the custody centres, participate in all activities, move around freely and conduct confidential interviews with all juvenile inmates. ${ }^{7}$

In what follows, I will first try to give an idea of the omnipresence of youth violence in the city of Salvador and the north-eastern state of Bahia, the escalating quality of the violence involved, and how both are related to the dynamics and shifting geography of the drug economy. Drawing on the ethnographic evidence collected, I will then examine the way the Brazilian state currently deals with the phenomenon of youth violence, focusing on three

\footnotetext{
${ }^{5}$ Delegacia do Adolescente Infrator (DAI).

${ }^{6}$ Comunidade de Atendimento Socioeducativo Brotas and Salvador (CASE Brotas, CASE Salvador). Most observations in this article are based on evidence from Brotas YDC.

${ }^{7}$ The author wishes to give expression to his gratitude to the Defensoria Pública do Estado da Bahia, Ministério Público do Estado da Bahia, Vara da Infância e da Juventude da Comarca de Salvador and the staff of Fundação da Criança e do Adolescente for their support of my research.
} 
institutional fields: policing, justice and confinement. Each of these fields would certainly deserve a more thorough discussion on its own. I've chosen to condense the analysis of the workings of these institutions as much as possible, however, in order to explore their interrelatedness. While each of them is meant to diminish youth offending and youth violence (and their representatives might publicly argue that they in fact do so), I will seek to demonstrate that it is not only each institution's actual (mal-)functioning that, in practice, makes them fail in this aim. On the contrary, from an empirical point of view, they seem to work hand in hand in fostering, rather than stemming, the process of marginalization of young citizens from the urban fringes, inducing those who have once come into contact with the police, the courts or custody centres to stick to, rather than give up, their violent offending behaviour.

As Comaroff and Comaroff (and others) have noted, the liberal ideology of the state as an "an essentially benign institution", which, in accordance with the Weberian model, legitimately exercises its monopoly over violence "in the name of protecting its citizenry from the threat of criminal disorder" falls short of accounting for the Janus-faced character of lawmaking and law-breaking, and the development of a "judicial apparatus designed to protect and reproduce the wealth of its dominant class fractions" (2016: 12). The histories and institutional experiences of juvenile offenders in Bahia I draw on are paradigmatic for this ambivalence of a criminal/juvenile justice apparatus which, in the present case, intermingles a sentencing philosophy based on ideas of citizenship, righteousness and responsibilization with an extra-legal eye-for-an-eye strategy of violent law enforcement, and an institutional reality of abandonment derived from sub-legal quid pro quo practices.

Rather than representing novel "strategies of crime control in contemporary society" (Garland 1996) or advanced liberal "regimes of control" for "the government of insecurity" (Rose 2000: 336), I argue that the workings of the police, the judiciary and the custodial system in Brazil are mainly expressions of a systematic (de)construction of identities of the criminal "Other", which suits the interests, inherent dynamics and laissez-faire attitude of the institutions entrusted with dealing with "violent" youth. As such, the ad hoc tactics employed by the police to halt youth violence (through inflicting violence against youths), the administration of youth justice by juvenile courts (through the imposition of incarceration in notoriously unsuitable custodial institutions), and the implementation of juvenile custody (in prison-like institutions prone to horizontal and vertical violence) are not strategies, but the outcome of an "anti-strategy" which accepts the violence perpetrated and suffered by 
marginalized youths as an unalterable social fact, inherent to their, supposedly chosen, condition of sub-citizens.

Mavelli has noted that violence has become "a governmental practice whose instrumental task is not, primarily, to contain or eliminate the threat stemming from certain populations, but to construct identities and subjectivities" (Mavelli 2016: 123). I will argue, however, that the propagation of the "bandit's" identity in Brazil is just as much a cause as it is a consequence of the state violence employed against juveniles. Thus, the corporeal punishment (and the eventual extermination) of a juvenile suspect by law enforcement agents, from the point of view of the police, seeks to contain the violence of someone who "carries" the crime in his own soul; $[\ldots]$ not someone who commits crimes, but [who] will always commit crimes" (Misse 2010: 21). At the same time, it is this very violence suffered which corroborates the social "branding" of young citizens as criminal "immanent others" who “threaten our 'good life' and 'deserve' their treatment" (Mavelli 2016: 117). Ultimately, it is the concerted outlawing of juvenile offenders by society at large which makes the law "apply in no longer applying" (Agamben 1998: 28) to them, and which, in turn, reinforces their identity as "lawless" subjects.

Consequently, the custodial sentence an offender eventually receives stems from a criminology which renders both the institutional violence a juvenile suffers preceding the trial and the violence he/she will suffer after the trial, although unlawful, as conceptually "just" within the lifeworlds of those who "chose" to become "bandits". Their incarceration in custodial institutions which knowingly violate their civic rights and, by means of the violence experienced within, reinforce their (self-)ascribed marginality, thus helps in shaping juvenile identities as much as it contributes to working out the very criminology it is based on. As a "working hypothesis" for juvenile justice institutions, it not only comfortable (inasmuch as it turns institutional malfunctioning into a virtue) but also "effective", as it verifies, as a selffulfilling prophecy, the general conviction that juvenile "bandits" are doomed to repeated incarceration or death before adulthood.

\section{Violent Youth}

According to the press, the assault on the city bus of which Jonathan and the police officer were victims was motivated by a drug debt of 95 Brazilian Real (around US\$27) the older of the two assailants (an unemployed house painter) had accumulated with the younger one. 
While allegations of involvement with drug trafficking are frequently cited by police whenever suspects are killed in the course of police action (euphemistically called, in Brazil, a "record of resistance", cf. Misse 2011), Jonathan had indeed been detained for drug possession a couple of months before. As his mother admitted, he was employed as an olheiro (look-out) by the drug faction operating in the neighbourhood where the family lived, a poor invasão (irregular settlement) behind Salvador's general hospital.

Hold-ups of buses are among the strategies used in Brazilian metropolises by whoever needs to make a considerable haul within a short period of time, like those who owe money to a boca (neighbourhood drug-selling spot). Together with street muggings, they have become endemic in Salvador, averaging around seven per day in $2015 .{ }^{8}$ Of the juveniles brought before the prosecutor in Salvador, a large number had built up significant debts with traffickers. Some owed money as a consequence of their own consumption "on credit", others had purchased drugs on commission and, for some reason or other, were unable to pay back their bosses. It is a common practice for senior traffickers in Salvador to lend out firearms for armed assaults which, naturally, have to be compensated for if things go wrong-making petty offenders accumulate further debts and eventually compelling them to resort to more profitable (and detrimental) forms of criminality.

Jonathan's case is paradigmatic of a youth being, at the same time, agent and victim of violence. Like many others of his generation, he was caught up and partaking in the crossfire between the violence ubiquitous in peripheral neighbourhoods, where the reach of state power is limited, and the violence perpetrated by or in the name of the state itself, through "the enactment of highly visible, public performances of violence and power" (Larkins 2015: 15). During the hearings of juvenile offenders this indiscernibility of youth as a perpetrator and as a victim of violence made itself constantly evident. On the one hand, possession of firearms by adolescents is widespread, and their use, either during muggings or during assaults of enemy drug factions, commonplace. In 2014, firearms caused more than 70 percent of all homicides in Brazil, and homicide rates start to rise steeply from a victim age of 12 years on, reaching their peak at age 20 (Waiselfisz 2015b: 21; 50). To be held up by an adolescent carrying a gun in Salvador has become common to the point that potential muggers don't actually need to carry or display a weapon: a great number of assaults investigated by the prosecutor had been committed with dummy pistols, or else simply by pointing, under the

\footnotetext{
${ }^{8}$ According to the Secretaria da Segurança Pública, in 2015 there were 2,561 assaults on public buses in Salvador (see: www.ssp.ba.gov.br/arquivos/File/Estatistica_2015/CAPITAL/03CAPITAL2015.pdf, accessed 3 May 2017).
} 
shirt, with the index finger towards the victims, shouting, for instance, "give me that cell phone so I won't kill you" (one offender).

While it doesn't take more than a gesture to hold up a passers-by, the use of real arms (which can easily be bought at some of Salvador's city markets) is only a trifle, even among schoolchildren. One 16-year-old offender, for instance, had borrowed a .38 revolver to "frighten" her classmates who, she said, were threatening her for going out with the wrong guy. Another 16-year-old juvenile (arrested with a revolver loaded with five bullets of the same calibre) confessed that his plan was to kill the boyfriend of a girl with whom he had been having an affair, and who had beaten him after finding out. Another schoolboy, aged 15, told how he had borrowed a .22 revolver and killed a fellow pupil aged 13 by firing two bullets into his head "because he kissed" his 14-year-old girlfriend.

On the other hand, deadly violence against youth has spread not only in the megalopolis of Salvador but throughout the state of Bahia. While there is little data available on youth offending in Brazil, the numerical "body count" of assassinated juveniles may give an idea of the ongoing proliferation of youth violence throughout the country. Just a decade ago, the cities of Rio de Janeiro and São Paulo were undisputed leaders in terms of the homicide statistics. In recent years, however, the Brazilian north and north-east have caught up and outstripped the former capitals of violence by far. While homicide rates went down 66 and 71 percent from 2002 to 2012 in Rio and São Paulo, they have rocketed 74 and 222 percent in the Northeast Region and the state of Bahia, respectively (Waiselfisz 2014: 52; 37).

This shift in the geography of violence is particularly marked as regards young citizens: in 2012, the homicide rate of youth aged 15 to 29 in the city of Salvador was nearly five times that of São Paulo, and of the seven most violent municipalities of the country, five were situated in the state of Bahia (2014: 58). Next to Salvador (and part of its metropolitan area), the tiny municipality of Mata de São João has become the unchallenged national leader of youth violence, with a homicide rate of more than 372 in 2012 (2014: 62). ${ }^{9}$ This is almost six times the overall homicide rate of the world's then most violent country, El Salvador (2014: 73) or, to cite another example, 20 times, 33 times and 929 times the youth homicide rate of South Africa, the US and Germany, respectively (2014: 73-74). ${ }^{10}$ While, as Comaroff and Comaroff stress, in South Africa "more people die of malnutrition-related diseases, tuberculosis, and traffic accidents than from criminal violence" (2016: 51), in Brazil the youth

\footnotetext{
${ }^{9}$ Per year per 100,000 inhabitants, youth aged 15 to 29 .

${ }^{10}$ Data from 2009, 2009, 2010 and 2011, respectively.
} 
homicide rate (below 20 years of age) in 2013 was double that of deaths from car accidents. Among juveniles aged 16 or 17 years of age, homicides accounted for almost half of all deaths registered (Waiselfisz 2015a: 15; 19).

The spread of violence from the Brazilian south and the cities of Rio de Janeiro and São Paulo to places even most Brazilians have never heard of (like Murici and Satubo, the runners up in homicide-by-firearms rates from 2012-2014, Waiselfisz 2015b: 42) is directly related to the dynamics of organized drug trafficking and the establishment of numerous drug factions in smaller cities of the Brazilian hinterland, and their struggle for local hegemony. In the course of the last two decades, the famous Primeiro Comando da Capital (PCC, "First Commando of the Capital") has managed to extend its near uncontested leadership throughout the state of São Paulo, today enjoying "a private monopoly of exercising violence" which allows it to "make use of well proportioned and graded forms and mechanisms of punitive control" (Dias 2011: 176; 259-60). In Bahia, the establishment of large-scale drug gangs is more recent, and numerous groups still compete fiercely for dominance. To give an example, Salvador's oldest faction, the Comando da Paz (CP, "Peace Commando"), founded towards the end of the 1990s within prison, has recently lost ground to a number of up-and-coming factions like the Bonde do Maluco (BDM, “Lunatics' Gang”) or Katiara, a small group of dedicated traffickers from the drowsy inland town of Nazaré das Farinhas, who have managed to dominate a number of neighbourhoods in the state capital.

Youths are employed by drug factions from a very early age and, having grown up in neighbourhoods with a well-established drug economy, "do not see involvement in drug trafficking as an abnormal activity" (Dowdney 2003: 132). Subordinated to the business practices of the drug trade, sooner or later, they almost inevitably become perpetrators and victims of notable violence. One of the inmates of Brotas Youth Detention Centre, for instance, explained that he "had to murder to avoid being killed". Being accused, by the chefão (big boss) of the area, of having sold $5 \mathrm{~kg}$ of cannabis on his own account, he was thrashed with a wooden club, until he eventually ended up putting the blame on another (innocent) member of the faction - who was subsequently beaten to death jointly by him and the other gang members present. The beating took place under the supervision of the chefão, who commanded that the victim should not be beaten on the head, "so that he wouldn't die [right away], but suffer".

Another youth offender (presented to the Youth Offending Services) had been on watch during a party of the Bonde do Maluco, in the course of which a locally well-known singer 
and composer was killed by the faction's local chief. After shooting the singer deadapparently because his cousin, though belonging to the same faction, was considered a business rival, so that his presence in the "wrong" neighbourhood had aroused suspicionsthe chief ordered that all gang members present should do their bit in cutting the victim's throat. During his hearing, the 16-year-old admitted that he had attempted, without success, to execute the chief's order, making an effort to decapitate the singer with the help of a fish knife. A second youth, presented to the prosecutor a couple of days later, confirmed his participation in like manner, and both were remanded in custody.

The juveniles' accounts attest to the degree of violence inherent in gang life, and the difficulties of staying out of the dynamics of killing once having joined. As has been noted (Dowdney 2003: 124; Misse 1997: 13), while there is no pressure for youths to join a drug gang, being member of a faction means to belong to a community within which the exercise of violence is part of the game. Moreover, youth who join one faction are continually under the threat of being victimized by the members the others, as soon as they leave the confines of their neighbourhood. Salvador's drug gangs employ a number of signs which are easily recognized by friend or foe. The allied Caveira and Bonde do Maluco, for instance, refer to themselves as "All Three" (Tudo Três), and (some of) their members shave three lines through their eyebrows, while the "All Two" members of the Comando da Paz use two lines. Analogous rules govern to the way members great each other, and the use of hand signs (with either two or three fingers), etc. Faction members who find themselves in the wrong place at the wrong time may thus quickly fall prey to the alemão ("the German", a term used to denote members of rival factions), often being tortured before their killing.

\section{Policing Youth Violence}

Of those youths who don't fall victim to their peers, a considerable share are put to death by the state itself. Jonathan's fate is indeed not an exception: in São Paulo, for instance, "the police were responsible for around 10 percent of the homicides of the metropolitan region" in 1999 (Caldeira 2013: 106). In the state of Rio de Janeiro alone, between 2001 and 2011, "more than 10,000 people died in clashes with the police", even only considering official numbers (Misse 2011: 4; 20; 23). In Bahia, in 2016, more than twice as many citizens were killed during police action than in the course of robberies. 
Misse has pointed to the fact that police work (in Rio de Janeiro) is based on a war-like modus operandi, which conceptually bisects the city into downtown street areas (asfalto) and informal urban settlements (favelas), within which "deadly police action is part of a public policy of fighting against crime" (2011: 120). While in Salvador the distribution of neighbourhoods considered "hot spots" for policing is somehow more homogeneous - not least for geographical reasons, as it lacks Rio's picturesque scenery of hills, historically areas of settlement of the poor - the relationship of marginalized youths and the police is clearly that of two parties at war. Police (ab)use of force is rife, and to receive a thrashing by the police as a juvenile suspect is ordinary to such an extent that one offender, being questioned at the prosecutor's office regarding a lesion on his face, spontaneously emphasized that it was not the result of a police beating.

A great many juveniles mentioned during the hearings that they had been "beaten up", "strangled", treated to "punches in the face and kicks in the stomach", pepper spray, "seven slaps in the face", or being suffocated "with a plastic bag over the head", to name just a few examples. The latter allegation of suffocation not only points to the use of professional techniques of torture, but may also demonstrate how juveniles adopt practices of violence "learned" from agents of the state. At the time of my research, inmates of Brotas YDC, apparently waterboarded one of their fellows to "convince" him to bring back some cannabis from weekend parole. As Larkins reports (2013: 566), investigation techniques based on suffocation are widely used by Rio's special law enforcement unit BOPE (Batalhão de Operações Policiais), and have been made notorious throughout Brazil by the semi-fictional blockbuster film Tropa de Elite ("Elite Squad")—a motion picture recommended to me by another inmate of Brotas YDC as a faithful portrayal of the violence engaged in by police and traffickers alike. Sentenced for robbery resulting in death, this juvenile knew what he was talking about: in the course of his questioning, a police officer had introduced a paperclip under his fingernail, "so that I would say who else was there".

Police use of force (deadly or not) in Brazil is closely related to notions of citizenship and moral economies which reflect the widespread conviction that there are "lives that are better dead than alive" (Scheper-Hughes 2015: 268). Lethal police action is considered justifiable "if the suspect was, at one point in his life, involved in criminal activities" (Misse 2011: 40). The narrative of juveniles from Salvador corroborated the importance of ascribed citizenship for the treatment an offender would receive from the police. One inmate of Brotas YDC, for instance, stated that the officers who detained him (he had committed a homicide and run over a motorcyclist while fleeing by car) were about to shoot him dead, arguing that "what I did 
was dreadful. They said I was a monster, a murderer, a terrorist." His life was spared, however, because another officer present happened to know his mother, who attended the same Protestant church - a fact which seemingly re-attached her son conceptually to the realm of citizens who deserve to live.

The workings of law enforcement at the margins of the state has helped traffickers to depict their own (mis)deeds as morally tantamount or superior to those of the representatives of the state. Traffickers' professed consideration for the concerns of the dwellers of the urban periphery, together with the framing of trafficking "as a form of politicized resistance to state oppression" (cf. Larkins 2013: 564; 2015: 31), has nourished, among a growing number of youths, a view of Brazilian polity within which the police are just another alemão, a state "faction" whose members don't seem to abide by the law any more than the so-called "bandits". In this regard, Wolff has noted that the "exceptionally violent strategies employed by the police" in Rio de Janeiro and Recife in the 1980s and 1990s created "moral incentives $[\ldots]$ to turn away from the state", particularly among youths $(2015: 22 ; 33 ; 27)$. Corroborating this observation, one of the inmates of Brotas YDC - who had received his first thrashing from the Military Police in Salvador when he was 13-remembered that: "From that day on, I really started to entertain myself doing robbery. I hit the streets, and robbed whoever I happened to meet."

\section{Judging Youth Violence}

Juveniles who have committed violent crimes or are considered repeated reoffenders are generally remanded in custody for a maximum of 45 days and subsequently brought before a judge. As was to be expected, the overwhelming majority of juveniles presented to the Juvenile Court in Salvador came from the lower and lowest strata of Brazilian society. Before being imprisoned, most of them were struggling to eke out a living from the limited economic opportunities in reach of the urban precariat. The three most common professions of juveniles standing trial were street vendor (of bottled mineral water and other petty goods like chewing gum, ice lollies, etc.), car washer and auxiliary construction worker. Nearly all of them had abandoned formal education after around five years of elementary schooling. Juveniles generally replicated the socioeconomic marginality of their parents, whose most common professions were domestic servant, cleaner and street vendor. 
The plain, office-like atmosphere of Salvador's juvenile justice court and the eschewal of any signs of elevation, segregation or disempowerment of the various court actors (cf. Hanson 1996: 57), could easily belie the extent to which the justice dispensed in these rooms is markedly a trial of the Other. In Bahia, the Brazilian state which comprises the municipalities with the highest proportion of Afro-descendants in the whole country, ${ }^{11}$ this Other is usually not only poor but also black. While around 22 percent of Bahia's population is white, the proportion of white Bahians in prison is only half of that. ${ }^{12}$ Black judges, prosecutors and public defenders, on the other hand, are a rare sight. ${ }^{13}$

As a matter of course, defendants belonged to a very different socioeconomic class than those entrusted to accuse, defend and judge them. They did so, however, to a notable extent: the average monthly total gross income of a first-instance state court judge in Bahia, at the time of writing, was R\$53,460.78 (around US\$ 16,093), ${ }^{14}$ which is more than 56 times the country's minimum wage of R\$ 937 (around US\$282)—compared to, for instance, 2.7 times in Germany. ${ }^{15}$ The ratio of economic capital present in most trials (between the average income of the judge, prosecutor and public defender ${ }^{16}$ on the one side, and that of the defendant and his/her parents on the other side), thus amounted roughly to that of the price of a Mercedes-Benz SUV compared to that of a quality wheelbarrow. ${ }^{17}$

While it may seem small-minded to subject the salary of public servants to scholarly scrutiny, this ratio is something to be kept in mind when anatomizing the local criminologies voiced by the different actors of the field of juvenile justice. Most theories of the causes of

\footnotetext{
${ }^{11}$ Seventeen out of twenty of the municipalities with the highest proportion of (self-declared) black people belong to the state of Bahia (IBGE 2011: 48).

${ }^{12}$ See IBGE (2011: Tabela 3175) and DEPEN (2016: 33). Racial statistics in Brazil have to be interpreted with care, as they rely on different classification schemes and procedures (e.g. "black" vs. "dark-skinned", ascription vs. self-identification).

${ }^{13}$ According to the judiciary census of 2013 (see: www.cnj.jus.br/pesquisas-judiciarias/censo-do-poderjudiciario, accessed 1 August 2017), in Bahia 10 percent of the employees and 5 percent of the judges declared themselves "black" (preto).

${ }^{14}$ Data of December 2017, according to CNJ, Remuneração dos Magistrados (www.cnj.jus.br/transparencia/remuneracao-dos-magistrados, accessed 9 March 2018).

${ }^{15}$ At the time of writing, a judge's starting salary in Germany was $€ 4,295.54$ in 2018, compared to a minimum wage of $€ 1,593$. See www.oeffentlicher-dienst.info/c/t/rechner/beamte/be?id=beamte-berlin2019\&matrix=1(category R1) and www.bmas.de/DE/Themen/Arbeitsrecht/Mindestlohn/Rechner/mindestlohnrechner html.

${ }^{16}$ Public Defenders in Brazil are public servants, trained in law and advocacy, and employed by a state agency (Defensoria Pública).

${ }^{17}$ The average total gross income of a state prosecutor in Bahia in November 2017 was R\$ 42,732.31, and that of a public defender in December 2017 R\$ 24,626.19 (see www mpba.mp.br/area/portaltransparencia/biblioteca/1316 and www.defensoria.ba.def.br/transparencia/gestaode-pessoas/quadro-de-defensores-publicos/, accessed 9 March 2018), totalling R\$120,819.28, or around US\$ 36,369. At the time of writing (accessed 1 August 2017), a Mercedes GLA 250 was listed at US\$ 33,400 (www mbusa.com/mercedes/vehicles); a "Big-4 Wheelbarrow" was listed at US\$271.93 (www homedepot.com/p/8-cu-ft-Heavy-Duty-Wheelbarrow-B4W-8/206625312).
} 
juvenile offending, voiced explicitly or implicitly in the course of offenders' trials, stressed the notion of a youth's supposed "personal choices". Judges and prosecutors would, for instance, suggest to defendants that "you still have the choice", "you could be a citizen", "you chose to live this kind of life" or that "you should think about what you want in life and make the right choices". At the same time, juveniles were accused of having deliberately "thrown away all your opportunities", "taken the road of crime" or "put yourself into a very dangerous environment".

Within the local judiciary's "criminology of the Other" (Garland 1996), juveniles standing trial were believed to favour the life of the "bandit" (bandido) over that of the "righteous citizen" (a pessoa do bem), thus having to cope with the "natural" consequences of their decision. Emphasizing that he had "never seen somebody being arrested in the library or at church", one judge explained to the defendant that there were "two possible roads of life: work, study, be a citizen [...] or die before you're 40".

Institutional violence was deemed an "unfortunate" but inevitable part of a bandit's life. "Is it wrong?", one judge rhetorically commented on the police violence a defendant had suffered. "It's wrong," he went on, "But that's the way it is. The police give a thrashing, and later they ask who you are ... They don't want to know." Another judge stated that "the police give a thrashing ... but that's how life is". Still another judge commented on the slaps a defendant had received from the police saying that "this is what a bandit's life is like: slaps in the face". Curiously, the police and traffickers were often mentioned in the same breath, stating, for instance, that defendants were at risk of being "killed by the police, killed by bandits", that "the trafficker kills, the police kill", or else that "whenever you go to buy drugs, you risk the police detaining you, beating you, giving you a thrashing".

The above quoted comments might convey the impression that the actors of the judicial field would condone police and other institutional violence. This is not the case, however. It regularly happened that, as a consequence of juveniles' hearings, prosecutors in Salvador demanded inquiries into police officers by the inspectorate, as did a number of judges and public defenders. Though not condoning institutional violence, it was, however, conceptualized as being intrinsic to the Brazilian polity and, particularly, to the lifeworlds of those who had made the "wrong choices".

Consequently, juveniles who had "decided" upon a bandit's life were considered to have forgone their citizenship, at least partly. The main markers used to gauge a youth's "degree" of citizenship were schooling, employment and the use of drugs. If, on the one hand, some 
judges asserted that "to work will protect you throughout life" or that "the only way to improve your life is to study", others affirmed that "it was the weed which took you where you are". Frequently, judges would inquire of a defendant's mother if this was a "wellbehaved boy" (um bom menino) and her response would be taken down as evidence in the case record.

Those juveniles who displayed signs of alleged relinquishment of citizenship (for having dropped out of school, or being idle or having been caught buying marijuana) were deemed co-responsible for the physical and symbolic violence eventually suffered in the course of their institutional treatment. This included not only physical harm through police action but also the conditions of custody in YDCs. Moreover, the prevalence of institutional violence was readily employed, if with no ill intent, as an argument to make juveniles revert to a "wellbehaved boy's" life. Alluding to the notorious conditions of pre-trial detention at Salvador YDC, for instance, defendants would be asked if they "enjoyed having being incarcerated there" (one judge) or if they "wanted to go back there" (another judge).

\section{Containing Youth Violence}

Most juvenile pre-trial and custody detention facilities in Bahia resemble adult penal institutions and suffer from the same vices, particularly overcrowding, horizontal and vertical violence (between inmates and/or between inmates and staff), sexual violence, internal drug trafficking and circulation of arms. One of the inmates of Brotas YDC, sentenced for homicide, recounted his time in Salvador YDC, where he was serving the initial period of his term, in the following way:

They started to do some "tests" with me. Some resistance tests. They lashed me onto the bars, pulled off my shirt, and assembled ten, twelve [fellow inmates], hitting me in the stomach. Onto the bars of the cell? Onto the bars, with the arms outflung, my feet short of the ground, and started to throw out punches into my stomach. They took a soft drink bottle, doesn't it have the part with the screw-cap? [...] They started to beat me, ten, twelve [inmates] ... with the bottle, that tip of the bottle, where you screw it open, taking off the cap. [...] If you beat it against the leg, it will bleed, if you beat with force. So they beat me, my leg started to bleed. [...] I told them: “Oh dude, you're beating up [...] a man. I ain't no rat [informer], if you want to beat me, you can even kill me.”

During the first three months of his stay, this juvenile, apart from the mentioned "resistance tests" (which should make sure he would keep his mouth shut about whatever was going on within the communal cell), was submitted "every day to something different" like, 
for instance, waterboarding "with the head in a bucket", or being wrapped in a sheet filled with cockroaches. Inmates' self-imposed rules were strict, and "every trifle, when you were not obeying this or that rule, this or that guy ... you would leave the cell completely battered, mouth, face, head, arm and leg broken". Punishments were decided on collectively: "There is no chief. Everybody decides. For instance: if, out of 24, 14 or 13 agree ... if these 13 decide to beat you up, then you're beaten up." Conflicts between different sectors of the YDC were frequent, and "if you were in the middle, you also had to fight. If you didn't fight, nothing would happen then. But later there would be a gathering, and you would lose support, or be beaten up."

The inappropriate conditions of Salvador YDC have long been publicly acknowledged by all local institutional actors in juvenile justice. ${ }^{18}$ Built in the 1970 s according to the prisonstyle architecture of the YDCs conceived during the military regime (Carrera 2005: 63), it was originally called the Centre for Reception and Triage of Minors, later renamed as the Centre for Refuge of Minors, and is today called the Socio-Educational Community Salvador (CASE Salvador). It has seen a number of military rulers and democratic governors come and go but, up to the present day, has undergone no more than "small repairs in terms of paint and the like" (Arruda 2011: 83). In 2014, the Youth Prosecution Service filed an action against the state of Bahia and FUNDAC, the state agency responsible for the implementation of juvenile custody, ${ }^{19}$ requesting the closure of Salvador YDC for its "sub-human conditions [...], lack of habitability, salubrity and hygiene". ${ }^{20}$

FUNDAC was founded in 1991 as the successor to the Bahian branch of the notorious National Foundation for the Wellbeing of Minors, itself the successor to the 1961 State Service of Assistance to Minors, baptized, by the press of the day, as the "subsidiary of hell" (Carrera 2005: 59). It was meant to put into practice the provisions of Brazil's modern Statute of the Child and Adolescent (ECA), passed in 1990 after the country's re-democratization, in accordance with the demands of the liberal Constitution of 1988 and international guidelines like the Beijing Rules and the United Nations Convention on the Rights of the Child.

FUNDAC's history is exemplary of the intricacies of Brazilian youth offending policies, and the way the state itself partakes in the propagation of violence of and against youths. The blatant contrast between the modern conception of the youth statute (ECA), as opposed to the

\footnotetext{
${ }^{18}$ Conditions in Salvador YDC have improved over recent years. and violence among inmates, while still commonplace, has receded considerably.

${ }^{19}$ Fundação da Criança e do Adolescente.

${ }^{20}$ ACP 0540192-12.2014.8.05.0001, $1^{\text {a }}$ Vara da Infância e Juventude, decision of 26 November 2015. A new pre-trial detention facility was inaugurated in August 2017.
} 
miserable conditions of actual custody, and the de facto relinquishment of the idea of rehabilitation of young offenders (the recidivism rate is around 85 percent; see Zoettl 2020), is notable. In Brotas YDC, every now and then, youth offending workers reported the death of a former inmate, nonchalantly showing around smart phone shots of young bodies—who had not long ago been released from or escaped state custody — wedged into the zippered plastic bags of the Medico-Legal Institute, with only their faces exposed. At the time of my research, Brotas YDC had turned into a near-abandoned institution, where inmates openly consumed marijuana, introduced firearms for their personal "protection" against the drug faction that dominated an adjoining neighbourhood and came and went at their convenience. ${ }^{21}$

The reasons for this chasm between the progressive legislation and retrogressive practice are to be found neither in a lack of public funds nor a lack of commitment of the majority of educators, psychologists and youth offending workers responsible for juvenile offenders in custody, but rather in politico-institutional dynamics. The early years of FUNDAC had been marked by a spirit of optimism and a strong impetus to fulfil the newborn Constitution's demand to ensure "young people, with absolute priority, the right to life, health, [...] education, $[\ldots]$ dignity, respect, freedom, $[\ldots]$ as well as to guard them from all forms of negligence, discrimination, exploitation, violence, cruelty, and oppression" (CF-88: 227). In subsequent years, however, FUNDAC was soon to became part of the local networks of political bargaining and clientelism.

FUNDAC's "vices" were promptly inscribed in its founding document of 1992, which determines the creation of no less than 94 "commissioned posts", to be designated at the discretion of its director, who, him/herself, is designated by the governor in office (D-1.203: Art. 38). Headed, at the time of my research, by the former wife of the Bahian governor in office, FUNDAC was described, in a recent investigation of the state Court of Audit, as "an ‘empty' entity [...] which effectuates practically all of its activities by means of outsourced personnel" (TCE/BA 2017: 5) from another foundation. That foundation-headed, at the time of my research, by the present wife of a member of the Bahian House of Representativesprovided the bulk of the staff actually dealing with juveniles, complementing FUNDAC's administrative personnel of 566 with another 1,700 full-time external employees. In 2015, FUNDAC's total annual expenditure amounted to R \$ 118.19 million (around US\$ 36

\footnotetext{
${ }^{21}$ At the time of writing, Brotas YDC was closed down and the inmates had been transferred to another semi-secure custody institution.
} 
million), that is, around US\$ 162 per day for every juvenile in custody-comparable to the average expenditure for juvenile custody in the $\mathrm{UK}^{22}$

\section{Youth, Violence and Justice}

Wacquant's caveat concerning Brazil's deployment of "the penal state to respond to disorders spawned by the [...] immiseration of large sections of the urban proletariat", condensed into the catchy slogan of a "dictatorship over the poor" (2003: 200), continues to be valid inasmuch as the country's prison population has increased by 136 percent over the past 13 years, maintaining its thoroughly homogeneous socioeconomic composition, with zero percent of prisoners with higher education. ${ }^{23}$ Wacquant's discussion falls short, however, of elucidating the causes of the proliferation of violent crime and its interplay with the dynamics of governmental crime management - which refuse to be reduced to the "social insecurity that everywhere pushes people into crime", the "enforcement of the class order" or a "political culture [...] of authoritarianism" (Wacquant 2003: 201; 199; 200).

Based on the experiences of juvenile offenders from Salvador, I argue that three aspects may primarily be held accountable for the notable increase in the quantity and quality of youth and state violence over the past decades in Brazil. The first of these is the bureaucratic pseudo-managerialism of crime control, under the sway of crony capitalism and rentier governance, where the exploitation of state monopolies (like the monopoly of the legitimate use of physical force, which includes institutional punishment) is commissioned to profitseeking entities as an obscure politico-financial quid pro quo. Second is the public Othering and scapegoating of a whole stratum of underprivileged youths from the socioeconomic periphery; and, finally, there is the mounting illegibility of the Brazilian state in general, and its law enforcement apparatus in particular, which has fuelled the escalation and reciprocal "doubling" of violence between state agents and juvenile citizens.

As Garland has argued, the erosion of "the myth that the sovereign state is capable of providing security, law and order" engenders novel governmental rationalities of either adaptation or denial, together with an "official criminology that fits our social and cultural configuration" (1996: 448; 462). In Brazil, the runaway proliferation of the organized drug

\footnotetext{
${ }^{22}$ According to the UK Audit Commission, each juvenile in custody cost $£ 50,800$ per year or around US\$ 172 per day (see Goldson and Muncie 2006: 150). On 17 April 2015, there were 602 juveniles held in custody by FUNDAC, according to the Central de Vagas e Regulação.

${ }^{23}$ See DEPEN (2016: 34). Numbers rounded to full percent by the reference source.
} 
trade and its successful enrolment of a steadily growing number of youths have resulted mainly in punitive state action, endorsed by a criminology which, first, emphasizes juveniles' personal responsibility for "choosing" to become "bandits" and, second, conceptualizes the great majority of juvenile offenders as incorrigible anti-citizens foredoomed to premature death or lifelong imprisonment (cf. Misse 2011: 116).

The societal consensus that juveniles who have once come into touch with trafficking will hardly ever turn into "righteous citizens" again has nurtured, throughout the field of juvenile justice, a pseudo-managerialism which neither emphasizes "economy, efficiency and effectiveness" (Garland 1996: 455) nor seeks to implement "policies that "work"” (Muncie 2006: 775), but has found its main vocation in the bureaucratic administration of juvenile marginalization itself, and the financial and political sinecures it may offer. Salvador's former Vocational School for Minors, housed in a colonial mansion in the "most salubrious locality of the Bahian capital" (Carrera 2014: 64), may serve as an allegory for this process: inaugurated in 1933, it came to serve 417 children in 1947, providing classrooms, refectory, infirmary, dental treatment, workshops for carpentry, woodwork, printmaking and a bindery. ${ }^{24}$ Today, the same building is exclusively occupied by the administrative personnel of FUNDAC, which oversees the custody of slightly more juveniles, out-housed to malfunctioning YDCs and being taken care of by outsourced contract employees.

While juvenile custody in Bahia has turned into a bargaining chip in the forging of local governmental alliances, the massive Othering of youths from the urban peripheries and their subsequent criminalization replenishes the already overcrowded YDCs, which often serve as an entry gate for the country's adult prison system, itself subject to a policy of privatization. In Brotas YDC, the majority of inmates had noticeably adopted their branding as "bandits" and seemed to anticipate a career behind bars. To give an example, one inmate, who had repeatedly been taken into custody for possession of arms and street muggings, justified his refusal to participate in an extramural bakery course arguing "Why should I learn a profession? I already have one!”

The self-fulfilling prophecy of the non-success of juvenile custody recalls not only Foucault's argument that "the supposed failure [is] part of the functioning of the prison" (1979: 271) but also Tilly's notion of the state as a protection racket (1985: 170-171). As has been demonstrated, Brazil's correctional institutions play a leading role in the organization

${ }^{4}$ See Carrera (2014: 73; 78; 209). The school was renamed as the Instituto de Preservação e Reforma in 
and consolidation of organized crime (see, for instance, Dias 2013: 211). The criminalization and incarceration of masses of juvenile citizens thus not only entails significant social costs, but also aids and abets their further marginalization, thus guaranteeing a continual supply of recruits for the country's drug factions - to be combated by the state by the same means that were conducive to its establishment, and so on.

Along with prison, death has become an unacknowledged but notorious constituent of Brazil's "public policy of crime fighting" (Misse 2011: 120), unfailingly victimizing the same demographic groups, that is, "young dwellers of the peripheries" (Dias et al. 2015: 165), "street kids, unemployed Black men, petty criminals, and vagrants" (Scheper-Hughes 2015: 289) or simply "black male bod[ies]" (Caldeira 2006: 136). In 2015/16, of all victims of police action in Brazil, 99 percent were male, young (82 percent aged from 12 to 29 years) and black (76 percent). ${ }^{25}$ As Misse has observed, "the mere fact of living in a favela with drug trafficking" sets a precedent "to assume the subjects' dangerousness and the legitimacy of their deaths" (2011: 134). Urban favelas in Brazil have come to display a number of characteristics Agamben attributes to concentration camps, particularly "the materialization of the state of exception [...] in which bare life and the juridical rule enter into a threshold of indistinction" (1998: 174).

However, the juvenile Brazilian homo sacer is generally not "killed by anyone" (Agamben 1998: 116), but either by his/her peers or the agents of the state. The ongoing carnage in the favelas, in which juveniles and state agents partake simultaneously as perpetrators and victims, rather points to Girard's (1977) notion of "mimetic violence". As Jonathan's case reminds us, it is not only juvenile bodies who fall victim to crime. In 2016, 453 police officers were killed in Brazil, 23 percent more than the year before (FBSC 2017: 23). For São Paulo, Dias et al. have traced a "cycle of action and reaction" in the lethal confrontations between the police and members of the PCC, which in 2012 issued a "General Order" (Salve Geral) determining that "for every member of the group executed by the police, two officers of the same police force shall be killed" (2015: 171).

Throughout Brazil, the deadly entanglement between the police and youths from drug factions has clearly come to bear signs of what Girard terms "monstrous doubling", the outcome of a "sacrificial crisis" in the course of which "the distinctions delegated to the members of society by the cultural order succumb to the reciprocal violence and are merged into a communal mass" (1977: 315). The increasing illegibility of Brazil's institutions of

\footnotetext{
${ }^{25}$ See FBSC (2017: 12-13; 31).
} 
political representation, judicature and law enforcement, the difficulties, not only of young citizens, in distinguishing dignitaries from villains, guilty from not guilty and good from bad, keeps fuelling this reciprocal emulation of violence. While juvenile offenders standing trial are reminded that they "could be a citizen" had they not chosen to be bandits, those who can afford a well-versed lawyer in Brazil may easily delay their sentencing indefinitely by filing successive petitions of habeas corpus. As Dowdney (2003: 134-135) remarks, "favela children understand the rules of trafficking from an early age" - and often far better than those of the society of the "righteous citizens".

The workings of extra-legal police use of force in Brazil are complex and, as has been noted, subject to shifting political conjunctures (Caldeira 2000; Misse 2011; Nunes 2018). For the present purpose, it suffices to note the extraordinary frequency and quality of the violence employed. Nearly all juveniles of Salvador YDC reported violent encounters with the police, and the majority had been subjected to varying techniques of torture which, remain etched in their memories:

"He laid me on the ground. You know this sack of fabric? Fabric or plastic? Of fabric, a sack of fabric.

Which is sewn. He put it on me, took a bottle of petrol, covered my head, and started to pour, so that I would swallow the petrol. At that moment there ... I thought that I would die. But that I wouldn't speak, that I won't say anything. That I will die like a man."

The account of this juvenile who, at the time of the interview, had been committed to the same YDC for the third time, points to the importance of notions of manhood in the battle between police and trafficker forces. The frequent clashes between heavily armed tactical units and adolescent traffickers represent, however, more than an unequal competition of masculinity. From a police point of view, torture and the eventual extermination of juvenile suspects are conceptualized as "violence [...] used for good, not for evil" (Larkins 2013: 567) exerted against "individuals considered 'incorrigible' and hence 'killable"” (Misse 2011: 40) — that is, as Girard would put it, as violence "that is limited for the sake of achieving or maintaining order" (Girard and Williams 1996: 70).

Yet, from the point of view of its victims, it is precisely this deliberate use of extra-legal violence which renders state action and the acts of enemy traffickers indistinguishable. As a consequence, the hatred many juveniles nurture for rival drug factions coalesces with their hatred for the police. The following quote of the same inmate of Salvador YDC gives an idea of how the violence suffered subsequently turns into a sentiment of hate, difficult to rein in, and which most likely will find expression in further violence, perpetrated by the former victim, and so on: 


\begin{abstract}
"If I come upon them [the police], it'll be a lot of bullets at them. Even if I die, it'll be a lot of bullets at them. You feel hatred for them? I do, and how! It's that often I don't like to express what I feel. But if I come upon them, wherever it'll be, in whatever situation ... If I'll have a grenade at hand, see a police car stopping, I throw the grenade inside the car. And beat it. If later they want to kill me, let them kill me. It's all the same to me."
\end{abstract}

As Girard's mimetic theory suggests, conflicts between equals "have the greatest risk of turning violent, because the social limitations that normally prevent or channel mimetic desire are missing" (Palaver 2013: 66). In Brazil, where the exercise of violence is less than ever exercised in the form of a legitimate state monopoly, the ultimate mimetic desire has become violence itself, seeking the extermination of the "immanent other" (Mavelli 2016). Where the "government of insecurity" has failed to "deliver security to the population at large" (Garland/Rose), the "fascination of superior violence" all the more "strikes men as at once seductive and terrifying; never as a simple means to an end, but as an epiphany" (Girard 1977: 152) - that is, the epiphany that good and evil, though apparently indistinguishable, might still be kept apart.

\title{
References
}

Agamben, Giorgio. 1998. Homo sacer. Sovereign power and bare life. Stanford, CA: Stanford University Press.

Arruda, Jalusa Silva de. 2011. "“Para ver as meninas": um estudo sobre as adolescentes em cumprimento de medida socioeducativa de internação na CASE/Salvador." Dissertação de Mestrado, Faculdade de Filosofia e Ciências Humanas. Salvador da Bahia: UFBA.

Caldeira, Teresa P. R. 2006. "“I Came to Sabotage Your Reasoning!” Violence and Resignifications of Justice in Brazil." Pp. 102-149 in Law and disorder in the postcolony, edited by Jean Comaroff and John L. Comaroff. Chicago: University of Chicago Press.

-. 2013. "The Paradox of Police Violence in Democratic Brazil." Pp. 97-124 in Policing and contemporary governance: the anthropology of police in practice, edited by William Campbell Garriott. New York: Palgrave Macmillan.

Caldeira, Teresa Pires. 2000. City of walls: crime, segregation, and citizenship in São Paulo: Univ of California Press.

Carrera, Gilca Oliveira. 2005. "Por detrás das muralhas: práticas educativas da medida de internação." Dissertação (mestrado), Programa de Pós-Graduação em Educação. Salvador da Bahia: UFBA.

—. 2014. "Educando os invisíveis: trajetória histórica dos internatos para preservação e reforma de menores da Bahia (1933/1950)."

CF-88. 2016. Constitution of the Federative Republic of Brazil. Official translation (Chamber of Deputies). Brazil. 
Comaroff, Jean and John L. Comaroff. 2016. The truth about crime: sovereignty, knowledge, social order. Chicago; London: The University of Chicago Press.

D-1.203. 1992. Decreto $n^{\circ} 1.203$ de 27 de maio de 1992. Aprova a resolução $\mathrm{n}^{\circ}$ 02/92, do Conselho Curador da Fundação da Criança e do Adolescente - FUNDAC. Bahia, Brazil.

DEPEN. 2016. Levantamento nacional de informações penitenciárias Infopen. Brasília: Departamento Penitenciário Nacional.

Dias, Camila Caldeira Nunes. 2011. "Da pulverização ao monopólio da violência: expansão e consolidação do Primeiro Comando da Capital (PCC) no sistema carcerário paulista." Universidade de São Paulo.

—. 2013. PCC: hegemonia nas prisões e monopólio da violência. São Paulo: Saraiva.

Dias, Camila, Maria Gorete Marques, Ariadne Natal, Mariana Possas, and Caren Ruotti. 2015. "A prática de execuções na região metropolitana de São Paulo na crise de 2012: um estudo de caso." Revista Brasileira de Segurança Pública 9(2): 160-179.

Dowdney, Luke. 2003. Children of the drug trade: A case study of children in organised armed violence in Rio de Janeiro. Rio de Janeiro: 7 letras.

ECA. 1990. Estatuto da Criança e do Adolescente. Lei no 8.069, de 13 de julho de 1990. Brazil: Presidência da República.

FBSC. 2017. Anuário Brasileiro de Segurança Pública 2017. São Paulo: Fórum Brasileiro de Segurança Pública.

Foucault, Michel. 1979. Discipline and punish: the birth of the prison. New York: Vintage Books.

Garland, David. 1996. "The Limits of the Sovereign State: Strategies of Crime Control in Contemporary Society." British Journal of Criminology 36(4): 445-471.

Girard, René. 1977. Violence and the sacred. Baltimore: Johns Hopkins University Press.

Girard, René and James G. Williams. 1996. The Girard reader. New York: Crossroad.

Goldson, Barry and John Muncie. 2006. Youth, crime and justice : critical issues. London ; Thousand Oaks, Calif.: SAGE. Available at: <Publisher description http://www.loc.gov/catdir/enhancements/fy0701/2005936297-d.html

Table of contents only http://www.loc.gov/catdir/enhancements/fy0701/2005936297-t.html> (accessed

Hanson, Julienne. 1996. "The architecture of justice: iconography and space configuration in the English law court building." arq: Architectural Research Quarterly 1(04): 50-59.

IBGE. 2011. Indicadores sociais municipais. Uma análise dos resultados do universo do Censo Demográfico 2010. Rio de Janeiro: Instituto Brasileiro de Geografi a e Estatística.

Larkins, Erika Robb. 2013. "Performances of Police Legitimacy in Rio's Hyper Favela." Law \& Social Inquiry 38(3): 553-575. DOI: 10.1111/lsi.12024.

—. 2015. The spectacular favela : violence in modern Brazil. Oakland, California: University of California Press.

Mavelli, Luca. 2016. "Governing uncertainty in a secular age: Rationalities of violence, theodicy and torture." Security Dialogue 47(2): 117-132. DOI:

$10.1177 / 0967010615613489$. 
Misse, Michel. 1997. "As ligações perigosas: mercado informal ilegal, narcotráfico e violência no Rio." Contemporaneidade e Educação 1(2): 93-116.

—. 2010. "Crime, sujeito e sujeição criminal: aspectos de uma contribuição analítica sobre a categoria 'bandido'." Lua Nova (79): 15-38.

-. 2011. Autos de Resistência: Uma análise dos homicídios cometidos por policiais na cidade do Rio de Janeiro (2001-2011). Rio de Janeiro: Núcleo de Estudos da Cidadania, Conflito e Violência Urbana, UFRJ.

Muncie, John. 2006. "Governing young people: Coherence and contradiction in contemporary youth justice." Critical Social Policy 26(4): 770-793.

Nunes, Samira Bueno. 2018. "Trabalho sujo ou missão de vida? Persistência, reprodução e legitimidade da letalidade na ação da PMESP." Tese de doutorado. São Paulo: Escola de Administração de Empresas de São Paulo.

Palaver, Wolfgang. 2013. René Girard's mimetic theory. East Lansing: Michigan State University Press.

Rose, Nikolas. 2000. "Government and Control." British Journal of Criminology 40(2): 321339. DOI: $10.1093 / \mathrm{bjc} / 40.2 .321$.

Scheper-Hughes, Nancy. 2015. "Death Squads and Vigilante Politics in Democratic Northeast Brazil." Pp. 266-304 in Violence at the urban margins, edited by Javier Auyero, Philippe I. Bourgois and Nancy Scheper-Hughes. New York, NY: Oxford University Press.

TCE/BA. 2017. Processo de contas administração indireta TCE/001897/2015. Ministério público de contas do Estado da Bahia. Parecer n 000329/2016.

Tilly, Charles. 1985. "War Making and State Making as Organized Crime." Pp. 169-191 in Bringing the state back in, edited by Peter B. Evans, Dietrich Rueschemeyer and Theda Skocpol. Cambridge Cambridgeshire; New York: Cambridge University Press.

Wacquant, Loïc. 2003. "Toward a dictatorship over the poor? Notes on the penalization of poverty in Brazil." Punishment \& Society Vol 5(2): 197-205.

Waiselfisz, Julio Jacobo. 2014. Mapa da Violência 2014. Rio de Janeiro: FLACSO.

—. 2015a. Mapa da violência 2015. Adolescentes de 16 e 17 anos do Brasil. Versão preliminar. Rio de Janeiro: FLACSO.

—. 2015b. Mapa da Violência 2016. Homicídios por armas de fogo no Brasil. Rio de Janeiro: FLACSO.

Wolff, Michael Jerome. 2015. "Building criminal authority: A comparative analysis of drug gangs in Rio de Janeiro and Recife." Latin American politics and society 57(2): 21-40.

Zoettl, Peter Anton. 2020. "Justiça Juvenil e Atendimento Socioeducativo na Bahia. Relatório de pesquisa." Zenodo. Available at http://doi.org/10.5281/zenodo.4292080. 